Bartosz Grabowy

Kraków

\title{
Główne Kościoły protestanckie w Polsce wobec kary śmierci
}

23 października 2014 roku papież Franciszek podczas spotkania z delegacją Międzynarodowego Stowarzyszenia Prawa Karnego poruszył kwestie dotyczące życia i godności ludzkiej w kontekście kary śmierci. Przypomniał stanowisko św. Jana Pawła II wyrażone numerze 56 encykliki Evangelium vitae oraz naukę płynącą z Katechizmu Kościoła katolickiego (nr 2267). Podnieść należy, że kara śmierci to tematyka ciągle aktualna w dzisiejszym świecie. O ile zazwyczaj tradycyjne argumenty „za” czy też „przeciw” jej stosowaniu oraz nauka Kościoła katolickiego są w Polsce powszechnie znane, o tyle już stanowisko chrześcijańskich wyznań niekatolickich niekoniecznie. Stąd pojawiła się idea zajęcia przedmiotowym problemem w niniejszym artykule.

Trzeba zauważyć, że dyskusja wokół kary kapitalnej ciągle trwa. Nie da się jej zakończyć w sposób kompromisowy, tj. w taki, by zrealizować postulaty tak represjonistów, jak i abolicjonistów, gdyż są one ze sobą sprzeczne. Niniejszy artykuł zbiera i systematyzuje stanowiska wobec najwyższego wymiaru kary największych Kościołów (wg kryterium liczby wiernych) protestanckich działających w Polsce, a jego celem jest zebranie i usystematyzowanie oficjalnych stanowisk oraz opinii teologicznych wyrażonych w kwestii kary śmierci przez te Kościoły. Celem niejako pobocznym jest ukazanie zagadnienia kary śmierci oraz ogólne przedstawienie protestantyzmu jako jednego z wyznań chrześcijańskich. 


\section{Kara śmierci}

Zagadnienie kary śmierci dotyczy ludzkości od czasów najdawniejszych, a instytucja ta jest tak stara, jak społeczeństwo ${ }^{1}$. Kara za przestępstwo to kara kryminalna i jest pokłosiem popełnienia przez sprawcę czynu zabronionego. Jest to ujemna reakcja na czyn zabroniony stosowana wobec sprawcy tego czynu i ma za zadanie zapobieżenie popełnieniu przestępstwa w przyszłości przez potencjalnych sprawców (prewencja ogólna) ${ }^{2}$. Większość przedstawicieli doktryny prawa karnego definiuje ją jako odwet, odpłatę, zemstę za wyrządzone zło.

Jak wskazano powyżej, śmierć to najstarszy znany człowiekowi sposób ukarania za dokonaną zbrodnię. Jej uzasadnienie wiąże się z powszechną zasadą odwetu - ius talione, a także z przekonaniem o jej odstraszającej funkcji ${ }^{3}$. Przez karę śmierci trzeba rozumieć wszystkie te sankcje prawnokarne, które polegają na pozbawieniu życia przestępcy. Jej rodowód wywodzi się z instytucji zemsty, znanej już w społeczeństwach prymitywnych ${ }^{4}$. Omawiana sankcja nazywana jest często karą główną, ostateczną, kapitalną lub najwyższym wymiarem kary. Był to kiedyś najpowszechniej stosowany rodzaj represji karnej-najczęściej jedyny. Przez szereg wieków była wykonywana publicznie, przez co stanowiła makabryczne widowisko dla gapiów ${ }^{5}$. W dziejach ludzkości nie ma okresu, w którym by nie występowała.

Pojawienie się prawa talionu stanowiło pewien postęp cywilizacyjny w rozwoju prawa karnego na świecie. W tym systemie śmiercią karano te czyny zabronione, których skutkiem była inna śmierć. W takiej właśnie postaci kara główna pojawiła się w Kodeksie Hammurabiego w Mezopotamii. Pozbawieniem życia można było być również ukaranym między innymi za nieudowodnione oskarżenie o morderstwo, krzywoprzysięstwo, paserstwo przedmiotów kultu religijnego, uprowadzenie małoletniego, ukrywanie zbiegłych niewolników, cudzołóstwo, gwałt oraz kradzież z włamaniem ${ }^{6}$. Podobnie sprawa przedstawiała się w hebrajskim systemie prawa Starego Testamentu. Żydzi uważali, że jedynie eliminacja zabójcy ze społeczeństwa jest dostateczną sankcją za zabójstwo. Izraelici śmiercią karali także grzechy przeciwko Bogu, rodzicom oraz cudzołóstwo. Formą wykonania było zazwyczaj ukamienowanie. W starożytnym Egipcie wśród różnorodnych sankcji

${ }^{1}$ Por. A. Bentkowski, Czy nowy kodeks karny bez kary śmierci?, „Palestra” 1994 nr 7-8, s. 130.

${ }^{2}$ Por. Encyklopedia prawa, red. U. Kalina-Prasznic, Warszawa 2007, s. 269.

${ }^{3}$ Por. A. Marek, Prawo karne, Warszawa 2009, s. 249.

${ }^{4}$ Por. M. Mitera, M. Zubik, Kara śmierci w świetle doświadczeń wspótczesnych systemów prawnych, Warszawa 1998, s. 32.

${ }^{5}$ Por. J. Warylewski, Prawo karne - częśś ogólna, Warszawa 2007, s. 430.

${ }^{6}$ Por. M. Stępień, Kodeks Hammurabiego, Warszawa 1996, §1, §2, §3, §6, §7, §8, §14, §15, $\S 16, \S 21, \S 22$. 
także występowała śmierć. Groziła ona za krzywoprzysięstwo, nieudzielenie pomocy osobie w potrzebie. Co ciekawe, z punktu widzenia stosunku do ludzkiego życia w tamtym okresie, niedozwolone było wykonanie kary na kobiecie w ciąży. Prawa greckie obowiązujące przed naszą erą były bardzo skomplikowane (w związku z formą państwa, a właściwie jego złożonością; państwa-miasta; polis). Pomimo swej surowości, reprezentowały nieco postępowy charakter. Ograniczano tu stosowanie śmierci, wprowadzono rozróżnienie pomiędzy zabójstwem umyślnym a nieumyślnym spowodowaniem śmierci. Najwyższy wymiar kary w starożytnej Grecji groził zazwyczaj za świętokradztwo, zdradę ojczyzny i korupcję ${ }^{7}$. W okresie rzymskim uśmiercenie to powszechna kara za obrazę bóstw, zabójstwo wolnego człowieka, zdradę państwa, podpalenie. Należy wskazać w tym miejscu, że egzekucja rzymska była bardzo okrutna: ludzi wywodzących się z plebsu palono żywcem, krzyżowano, rzucano na pożarcie dzikim zwierzętom. Obywateli najczęściej ścinano mieczem, ale jeżeli dopuścili się oni zdrady lub obrazy majestatu, to karano ich jak niewolników i pospólstwo.

W średniowieczu kara główna stanowiła podstawową karę publiczną. Metody jej wykonywania były widowiskowe i niezwykle drastyczne (np. łamanie kołem, rozrywanie końmi, ćwiartowanie ciała). Celem miała być przede wszystkim prewencja ogólna.

Pierwszym krajem, w którym zniesiono karę śmierci było Wielkie Księstwo Toskańskie (Kodeks Karny Leopolda II z 1786 roku). Osiemnastowieczny włoski prawnik Cesare Beccaria postulował powolne odchodzenie od tej represji karnej. Mimo to kara kapitalna nadal była stosowana powszechnie. Nie zapomniano jednak o przemyśleniach Beccarii i zgodnie z nimi ograniczano katalog czynów zagrożonych śmiercią.

Do roku 196512 państw zniosło w systemach prawnych karę śmierci, a 11 zrezygnowało z jej orzekania podczas pokoju. W 2013 roku w 98 państwach brak w systemie karnym kary głównej, a oficjalnych egzekucji wykonano na całym świecie 778 (wyłączając ChRL, gdzie dane o liczbach wykonanych egzekucji pozostają tajne). Warto $\mathrm{w}$ tym miejscu zaznaczyć, że stosowanie kary śmierci w Republice Iraku, Islamskiej Republice Iranu, Królestwie Arabii Saudyjskiej, Republice Jemeńskiej, Federalnej Republice Somalii i Federalnej Republice Nigerii stanowi większość odnotowanych straceń ${ }^{8}$.

W systemach prawnych państw, które nadal stosują śmierć w swoim katalogu kar kryminalnych, jest ona orzekana za tzw. przestępstwa polityczne, czyli czyny zabronione dokonane na szkodę państwa (zdrada, szpiegostwo, pucz, zamach

\footnotetext{
${ }^{7}$ Por. B. Bartusiak, Kara śmierci w świetle sporu o racjonalizacją kary, Warszawa 2011, s. 143-144.

${ }^{8}$ Por. Death sentences and executions 2013, Amnesty International Publications 2014, http:// www.amnestyusa.org/research/reports/death-sentences-and-executions-2013 (28.06.2014).
} 
na głowę państwa), zabójstwo, w niektórych w ten sposób karany jest terroryzm (np. Egipt), handel narkotykami (np. Tajlandia). Kilkadziesiąt państw utrzymało ją za przestępstwa gospodarcze (np. Białoruś, Chińska Republika Ludowa). W krajach islamskich śmiercią mogą być ukarani cudzołożnicy, apostaci, homoseksualiści. W Iranie zakres stosowania kary śmierci jest znacznie szerszy. Można ją tam orzec za kazirodztwo, picie alkoholu, handel „,nieprzyzwoitymi” towarami, rozpowszechnianie pornografii. Co ciekawe, w niektórych państwach można zostać ukaranym w ten sposób za uprowadzenie (np. Gwatemala, Republika Chińska), a w Indiach śmiercią zagrożona jest pomoc w sati, czyli samospaleniu kobiety na stosie pogrzebowym męża. Szeroki pozostaje katalog przestępstw wojskowych, za które można stracić życie. W większości państw możliwość orzeczenia kary śmierci występuje jednak jedynie w czasie wojny lub stanu wyjątkowego. Forma egzekucji to zazwyczaj powieszenie lub rozstrzelanie. Stosowane jest też wstrzyknięcie trucizny, stracenie na krześle elektrycznym, zagazowanie. W krajach islamskich za cudzołóstwo praktykuje się ukamienowanie, a w Królestwie Arabii Saudyjskiej i Republice Jemeńskiej wykonanie kary następuje przez ścięcie mieczem?.

Problematyka dotycząca kary głównej zajmuje bardzo eksponowane stanowisko w nauce prawa karnego i jest zazwyczaj zarzewiem wielu sporów filozoficzno-prawnych ${ }^{10}$.

\section{Protestantyzm}

Protestantyzm to główny obok prawosławia i katolicyzmu odłam chrześcijaństwa, który obejmuje Kościoły i wspólnoty religijne powstałe bezpośrednio lub pośrednio w wyniku tzw. Wielkiej Reformacji ${ }^{11}$. Samo słowo „protestantyzm” pochodzi od łacińskiego protesto, -are, i oznacza tyle co sprzeciwiać się. Pojęcie to znajduje potwierdzenie w historii; w 1529 roku parlament ogólnoniemiecki zwołany w Spirze podjął uchwałę, która zabraniała szerzenia reformujących haseł luterańskich. Przeciwko temu aktowi zaprotestowali przedstawiciele kilkunastu księstw i miast niemieckich, a od ich wystąpienia pochodzi właśnie nazwa „protestanci”, którą w późniejszym czasie rozszerzono na pochodne głównego nurtu reformatorskiego związanego z ks. dr Marcinem Lutrem, Janem Kalwinem

${ }^{9}$ Por. M. Mitera, M. Zubik, Kara śmierci w świetle doświadczeń wspótczesnych systemów prawnych, dz. cyt., s. 46-50.

${ }^{10}$ Por. A. Grześkowiak, Kara śmierci w polskim prawie karnym, Toruń 1982, s. 15.

${ }^{11}$ Por. Nowa encyklopedia powszechna PWN, red. B. Petrozolin-Skowrońska, t. 5, Warszawa 1995, s. 347. 
i innymi reformatorami religijnymi. Przyjmuje się, że reformacja rozpoczęła się 31 października 1517 roku od ogłoszenia przez Lutra w Wittenberdze tez wymierzonych przeciwko m.in. instytucjom odpustów papieskich.

Współczesny protestantyzm dzieli się na dziesiątki, jeśli nie steki odrębnych (organizacyjnie) Kościołów, związków wyznaniowych czy zrzeszeń religijnych. Tylko część z nich wykazuje przywiązanie do reformacyjnych fundamentów, a reszta jest swoistą mieszanką najróżniejszych prądów, kierunków i tendencji ideowych.

Źródłem doktryny protestanckiej są przede wszystkim zasady sformułowane przez Lutra, a mianowicie sola fide - tylko wiara, sola Scriputra - tylko Pismo, solus Christus - jedynie Chrystus, solum Verbum - jedynie Słowo, sola gratia, sola fide - jedynie łaska i jedynie wiara.

Pierwsza z powyższych zasad oznacza, że jedynym źródłem wiary i życia każdego chrześcijanina powinna być Biblia. Nie może tych sfer kształtować dogmatyka czy tradycja. Wszystko, co nie jest zgodne ze słowami Pisma Świętego, musi zostać odrzucone. Reguła solus Christus wskazuje, iż zbawicielem świata, pośrednikiem pomiędzy Bogiem, a człowiekiem jest Jezus Chrystus. Tylko Jego można uwielbiać i tylko Jemu oddawać cześć . Nie ma innych pośredników pomiędzy Bogiem a człowiekiem w drodze do zbawiania. Zasada trzecia stanowi, że zbawienie udzielane jest tylko przez Słowo Boże i jest ono udziałem wszystkich, którzy go słuchają i korzystają z sakramentów zgodnie z zaleceniami Chrystusa. Jedynie Duch Święty daje poznanie grzechu, świadomości śmierci i działalności Szatana. Przez wiarę w Słowo budzi się wiarę w zbawienie. Sprawuje się dwa sakramenty - chrzest i Wieczerzę Pańską jako ustalone przez samego Syna Bożego. Ostatnia zasada odnosi się do łaski Bożej, która uprzedza wszystkie działania ludzkie. Praktyki kościelne i dobre uczynki bez wiary nie dają zbawienia. Zbawić człowieka może jedynie Chrystus przez swoją śmierć, a wiara rodzi się jedynie ze Słowa. To ona jest źródłem dobrych uczynków ${ }^{12}$. Chrześcijanie reformowani kładą nacisk na zindywidualizowany dostęp człowieka do Boga - bezpośrednią więź, bez pośrednictwa Kościoła i kapłanów. Zatem uznają oni wyższość Kościoła niewidzialnego, który obejmuje wszystkich chrześcijan, nad Kościołem widzialnym - zinstytucjonalizowanym. Za doktryną sola Scriptura płynie indywidualizm i swoista wolność religijna, która daje swobodę do badań nad słusznością poszczególnych dogmatów. Związany jest z tym negatywny stosunek do kościelnych autorytetów, a zwłaszcza do prymatu biskupa rzymskiego. Cechy

${ }^{12}$ Por. K. Borkowski, Kościół Ewangelicko-Augsburski w RP, [w:] Kościoły chrześcijańskie zrzeszone w Polskiej Radzie Ekumenicznej. Informator krakowski, red. M. Poniewierska, Kraków 2006, s. 6. 
te są charakterystyczne w większym lub mniejszym stopniu dla każdej konfesji protestanckiej ${ }^{13}$.

Ruch reformacyjny jest niezwykle złożony. Nie da się go jednolicie usystematyzować. Można jedynie zaznaczyć główne występujące w nim nurty:

a. reformacja luterańska, z której wywodzi się ewangelicyzm augsburski;

b. reformacja kalwińska, z której wyszedł ewangelicyzm reformowany, a na gruncie anglosaskim purytanizm, prezbiterianizm i baptyzm;

c. reformacja anglikańska, która przyniosła anglikanizm i później metodyzm;

d. nurty uboczne, często równoległe do powyższych - unitarianizm, husytyzm, odłamy pietystyczne (adwentyści, mormoni, zielonoświątkowcy), ugrupowania parachrześcijańskie, jak np. Świadkowie Jehowy ${ }^{14}$.

Organizacyjnie w protestantyzmie występują cztery rodzaje ustroju kościelnego: episkopalny - wsparty na władzy biskupów, konsystorialny - gdzie władzę pełni konsystorz, czyli rada składająca zarówno z duchownych, jak i świeckich, synodalny - władzę sprawują synody i kongregacjonalny - samodzielność poszczególnych gmin (parafii). W większości przypadków Kościoły te są samodzielne organizacyjnie w obrębie poszczególnych państw ${ }^{15}$.

W Polsce największymi (najliczniejszymi) Kościołami tradycji protestanckiej są:

- Kościół Ewangelicko-Augsburski w RP: luteranizm;

- Kościół Ewangelicko-Reformowany w RP: kalwinizm;

- Kościół Ewangelicko-Metodystyczny w RP: metodyzm;

- Kościół Chrześcijan Baptystów w RP: baptyzm;

- Kościół Adwentystów Dnia Siódmego w RP: adwentyzm;

- Kościół Zielonoświątkowy w RP: pentekostalizm.

\section{Kara śmierci w doktrynie Kościołów protestanckich działających w Polsce}

\subsection{Kościół Ewangelicko-Augsburski w RP}

Kościoły luterańskie opierają się na dorobku swego twórcy - ks. dr Marcina Lutra. W traktacie $O$ zwierzchności świeckiej z 1523 roku Luter zajmuje się analizą Listu do Rzymian św. Pawła. Zauważa on, że gdyby wszyscy ludzie byli naprawdę wierzący, to zbędna byłaby jakakolwiek władza. Ludzie jednak z natury

\footnotetext{
${ }^{13}$ Por. S. Włodarski, W. Tarowski, Kościoły chrześcijańskie, Warszawa 1968, s. 107-108.

${ }^{14}$ Por. tamże, s. 108.

${ }^{15}$ Por. Nowa encyklopedia powszechna PWN, t. 5, dz. cyt., s. 348.
} 
są źli, więc musi wisieć nad nimi miecz jako symbol kary i władzy. W państwie świeckim trzeba wykonywać rozkazy władzy państwowej i oddawać jej cześć, gdyż ona pochodzi od Boga. Władza trzyma w ręku miecz, może używać przemocy, by chronić ludzi pobożnych przed grzesznikami ${ }^{16}$. Luter zezwalał więc na stosowanie kary śmierci jako dopuszczanej przez samego Chrystusa, który w ogrodzie Oliwnym powiedział do Piotra, gdy ten dobył miecza, by bronić Go przez faryzeuszami: „wszyscy bowiem, którzy miecza dobywają, od miecza giną" (Mt 26, 52) $)^{17}$.

Jeżeli chodzi o stanowisko Kościoła Ewangelicko-Augsburskiego w RP, to zawarte jest ono w oświadczeniu z 1991 roku. Dokument jest praktycznie cały poświęcony aborcji, jednak pod koniec znajduje się zdanie: „Poważne potraktowanie tematu ochrony życia domaga się także zniesienia kary śmierci"18.

Sformułowanie to nie pozostawia żadnych wątpliwości, że współczesny polski luteranizm - Kościół Ewangelicko-Augsburski w RP - odnośnie do kary śmierci wyraża stanowisko abolicjonistyczne. Zważywszy jednak na datę wymienionego dokumentu, zasadne byłoby zaktualizowanie przez ten Kościół swojego zdania na ten temat.

\subsection{Kościół Ewangelicko-Reformowany w RP}

Drugi z kolei wielki reformator religijny - Jan Kalwin - w 1539 roku w komentarzach do Listu św. Pawła do Rzymian wskazuje, że celem władców powinna być troska o dobro publiczne, i że zostali powołani przez Boga, aby sprawować swe rządy zgodnie z prawami Bożymi dla dobra obywateli. Społeczeństwo winne jest zatem posłuszeństwo wobec prawa stanowionego. Najdokładniej o zadaniach należących do władzy świeckiej Kalwin wypowiada się w dziele Institutio Christianae religionis z roku 1559. Podkreśla w nim, że władza nie powinna działać poprzez swoje władcze instrumenty jedynie w sytuacjach nadzwyczajnych, lecz w każdej sytuacji społecznie niebezpiecznej. Dochodząc do najważniejszego zagadnienia z punktu widzenia niniejszej pracy, Jan Kalwin wskazuje, iż świeccy rządcy w obronie Kościoła, religii i porządku publicznego mogą odwoływać się do władzy miecza, czyli stosować karę kapitalną. Władcy są powołani do otaczania surową troską całego społeczeństwa i wspólnoty kościelnej, tak jak pater familias otacza opieką swoją rodzinę. Przy wykonywaniu władzy należy postępować

${ }^{16}$ Por. M. Hinz, Marcin Luter - ojciec etyki ewangelickiej, [w:] M. Luter, Pisma etyczne, Bielsko-Biała 2009, s. 23-24 (Biblioteka Klasyki Ewangelickiej, 6).

${ }^{17}$ Por. M. Luter, Pisma etyczne, dz. cyt., s. 181.

${ }^{18}$ Oświadczenie Kościoła Ewangelicko-Augsburskiego w sprawie ochrony życia z 1991 r., http://old.luteranie.pl/pl/?D=3353 (29.06.2014). 
zgodnie z wykładnią Pisma Świętego i liczyć się z Dekalogiem ${ }^{19}$. Warto przytoczyć w tym miejscu słowa samego Kalwina o stosowaniu kary śmieci:

Nagrodą i karaniem wszystki rzeczypospolite stoją, tego gdzie nie masz, prętko dobry rząd zginąć musi. [...] Niewinnych bronić i miłować jest sprawiedliwość czynić. Sąd zaś wykonywa, gdy niezbożnych śmiałość krócona bywa karnością występków. [...] przełożeni w karaniu złych uczynków nie czynią nic sami z siebie, ale sądy Boże wykonują. Zabijać wprawdzie zakon Boży zakazuje, ale tenże Bóg dał też prawo zwierzchności, aby mężobójstwa i występki insze karano, dla tego im dał miecz, aby go na jego miejscu używali. Szkodzi i psować pobożnym nie należy, ale to nie jest psowanie, gdy występni i swowolni karanie biorą $[\ldots]^{20}$.

Kościół Ewangelicko-Reformowany w RP nie zajął oficjalnie stanowiska wobec kary śmierci. Aby poznać współczesny stosunek spadkobierców nauki Kalwina do tej kary, warto spojrzeć na doktrynę reformowaną w USA, gdzie dyskusja wokół stosowania kary głównej jest zawsze bardzo wzmożona. Należy w tym miejscu przytoczyć należy poglądy największych Kościołów tradycji kalwińskiej w tym kraju, a mianowicie Kościoła Reformowanego w Ameryce (Reformed Church in America) oraz Zjednoczonego Kościoła Chrystusa (United Church of Christ).

Ten pierwszy na temat kary śmierci wypowiedział się trzykrotnie: w 1965, 1966 oraz 2000 roku. Wspólnota ta w uchwale Synodu Generalnego właśnie z 2000 roku wskazuje, że kara śmierci jest niezgodna z Duchem Chrystusa i etyką miłości. Ma ona również wątpliwą wartość odstraszającą. Kościół ten wskazuje także, że w celach śmierci znajduje się coraz więcej niewinnych osób, a kary tej nie da się cofnąć. Utrwala ona w świadomości społecznej takie pojęcia, jak zemsta i odwet, a przecież państwo jako instytucja stosująca sankcje karne nie powinno występować w roli mściciela. Śmierć uniemożliwia również rehabilitację sprawcy, a skoro wiara chrześcijańska oparta jest na odkupieniu i przebaczeniu, to nie można aprobować kary głównej ${ }^{21}$.

Drugi z wymienionych Kościołów wydał dwa oficjalne stanowiska w tej sprawie (1969 i 2005 rok). W tym ostatnim wyrażono opinię, że każde morderstwo jest z założenia złe, niezależnie od tego, czy zostaje popełnione prywatnie przez

${ }^{19}$ Por. W. Kriegseisen, Wstęp, [w:] J. Kalwin, O zwierzchności świeckiej, porządne wedtug sznuru Pisma świętego opisanie. Zaraz o pożytkach i powinnościach urzędu jej. Z łacińskiego na polskie wiernie przettumaczone, oprac. W. Kriegseisen, Warszawa 2009, s. 8-13.

${ }^{20} \mathrm{~J}$. Kalwin, O zwierzchności świeckiej, porządne wedlug sznuru Pisma świętego opisanie..., dz. cyt., s. 77-79.

${ }^{21}$ Por. Reformed Church in America, Position on capital punishment (2000), https://www.rca. org/sslpage.aspx?pid=496 (29.06.2014). 
osobę fizyczną, czy w imieniu i na zlecenie państwa ${ }^{22}$. Zjednoczony Kościół Chrystusa apeluje tym samym o zniesienie kary śmierci.

Mimoże Kościół Ewangelicko-Reformowany w RP nie zrzesza dużej liczby wiernych, stosowne byłoby wyrażenie przezeń własnego stanowiska w przedmiotowej sprawie lub zaaprobowanie oświadczeń bratnich Kościołów reformowanych.

\subsection{Kościół Ewangelicko-Metodystyczny w RP}

Pierwszy z metodystów - Jan Wesley - w swoim komentarzu do Listu do Rzymian uznaje wszelką władzę jako zgodną z Bożą wolą. Wskazuje on, że jurysdykcja państwowa jest powoływana przez Boga i Jemu podporządkowana, przez co pełni rolę niejako zastępcy, namiestnika Boga na ziemi. Ktokolwiek sprzeciwi się władzy, otrzymuje karę zarówno świecką, jak i boską. Rządzący państwami powinni być postrachem dla złych uczynków. Bóg wkłada w rękę swoich namiestników miecz, a jest on narzędziem kary śmierci, którą Bóg pozwala zadać ${ }^{23}$.

Kontynuatorem nauki metodystycznej w Polsce jest Kościół EwangelickoMetodystyczny w RP. Wyraził on swoje zdanie w kwestii kary śmierci w oficjalnym dokumencie Zasady socjalne uchwalonym przez Zjednoczony Kościół Metodystyczny, w skład którego wchodzi polska wspólnota. Zjednoczony Kościół Metodystyczny uznaje, że władze są odpowiedzialne za ochronę praw człowieka w danym państwie. Stanowczo sprzeciwia się karze śmierci jako naruszającej nauczanie chrześcijańskie. Metodyści wzywają do całkowitego wyeliminowania tej sankcji z prawa karnego ${ }^{24}$. Jest to zatem stanowisko stricte abolicyjne.

\subsection{Kościół Chrześcijan Baptystów w RP}

Należy pamiętać, iż wyznanie to nie ma swojego założyciela, a baptyzm wywodzi się poniekąd i czerpie z dorobku kalwińskiego ${ }^{25}$. Kościół Chrześcijan Baptystów w RP nie wyraził oficjalnego zdania dotyczącego kary kapitalnej. Aby ukazać pogląd na temat stanowiska środowiska baptystycznego w sprawie kary

${ }^{22}$ Por. United Church of Christ, Capital punishment, http://www.ucc.org/justice/criminal-justice/ death-penalty.html (30.06.2014).

${ }^{23}$ Por. J. Wesley, Bible commentary notes, http://www.godrules.net/library/wesley/wesleyrom13. htm (25.06.2014).

${ }^{24}$ Por. Zasady socjalne 2000-2004. Nauka społeczna Zjednoczonego Kościoła Metodystycznego, red. E. Puślecki, Z. Kamiński Warszawa 2003, s. 48-49.

${ }^{25}$ Por. T. J. Zieliński, Krótka informacja o Kościele baptystycznym, http://www.baptysci.pl/ kosciol/1141-krotka-informacja-o-kosciele-baptystycznym (25.06.2014). 
śmierci, zasadne jest przytoczenie poglądów Południowej Konwencji Baptystów (Southern Baptist Convention) z USA (jako największego Kościoła tej konfesji chrześcijańskiej) wyrażonego w rezolucji z czerwca 2000 roku. Amerykańscy baptyści w owym dokumencie zauważają, że Bóg zabrania osobistej zemsty i dlatego ustanowił karę śmierci jako sprawiedliwy i odpowiedni środek, dzięki którym świecki sędzia może ukarać przestępcę winnego najcięższych zbrodni. Wierni wskazują, że Bóg przed ukaraniem wymaga najpierw rzetelnego udowodnienia winy, a skazany, który jak każdy człowiek został stworzony na obraz Boga, powinien być traktowany godnie. Zważywszy na tę godność, jeżeli kara śmierci zostaje uczciwie orzeczona, powinna zostać wykonana bez zbędnej zwłoki ${ }^{26}$.

Zatem trzeba skonstatować, iż baptyści reprezentują swoim stanowiskiem stanowisko właściwe represjonistom, którzy opowiadają się za stosowaniem kary śmierci.

\subsection{Kościół Adwentystów Dnia Siódmego w RP}

Uważany za twórcę ruchu adwentowego William Miller był baptystą, dlatego można przyjąć, że podzielał przekonania innych baptystów i poprzez to pośrednio dawał wiarę nauce Jana Kalwina.

Powszechny Kościół Adwentystów Dnia Siódmego (w skład którego wchodzi Kościół Adwentystów Dnia Siódmego w RP) nie wyraził nigdy oficjalnego stanowiska w kwestii kary śmierci. Analizując jednak piśmiennictwo adwentystyczne jak również wypowiedzi duchownych ${ }^{27}$, można wywnioskować, że wyznawcy tego protestanckiego Kościoła podzielają stanowisko baptystyczne.

\subsection{Kościół Zielonoświątkowy w RP}

Wspólnota zielonoświątkowa czerpie z dorobku metodystycznego, gdyż uważani za prekursorów pentekostalizmu Charles Fox Parham oraz William Joseph Seymur byli duchownymi tego wyznania chrześcijańskiego ${ }^{28}$.

${ }^{26}$ Por. Southern Baptist Convention, Resolution on capital punishment (2000), http://www.sbc. net/resolutions/299

(26.06.2014).

${ }^{27}$ Por. G. W. Reid, Death penality, http://dialogue.adventist.org/articles/08_1_kubo_e.htm (24.06.2014).

${ }^{28}$ Por. W. Gajewski, Kościól zielonoświątkowy: geneza, dzieje, teologia, duchowość i perspektywy, [w:] Nierzymskokatolickie Kościoły chrześcijańskie we współczesnej Polsce, red. Z. J. Winnnicki, T. Dębowski, Torun 2007, s. 119-124. 
Kościół Zielonoświątkowy w RP nie ustosunkował się do kwestii kary śmierci. Zielonoświątkowcy jednak uważają, że państwu i władzy należny jest szacunek i posłuszeństwo. Wszak władza pochodzi od Boga. Chrześcijanin nie powinien się mieszać do polityki, ma podporządkować się władzy, chyba że ta zmusza do naruszenia Dekalogu i nakazów Pisma Świętego. Wyznawcy tej konfesji na Zaolziu w 1963 roku w oficjalnym dokumencie zaznaczyli, że „członkowie Kościoła poddają się zawsze władzom świeckim za wyjątkiem wykonywania rzeczy sprzecznych względem Boga" ${ }^{29}$. Warto przytoczyć również opinię największego Kościoła nurtu pentekostalicznego, a mianowicie Zborów Bożych (Assemblies of God) z USA, który kary śmierci nie neguje (jako zgodną z nauką płynącą z Biblii), ani też jej nie popiera (jako, że życie ludzkie jest święte) $)^{30}$.

Wychodząc z złożenia, że Biblia nie zabrania karania śmiercią można uznać, że jeżeli państwo taką karę utrzymuje w katalogu kar prawa karnego, to zielonoświątkowcy się jej nie sprzeciwiają. Stanowisko jest więc neutralne.

\section{Podsumowanie}

Kara śmierci funkcjonuje na świecie od czasów najdawniejszych, a w Polsce obowiązywała od samego początku istnienia państwa. W wielu krajach nadal jest utrzymywana, głównie za przestępstwa polityczne i zabójstwo. Aktualne prawo międzynarodowe jest ukierunkowane na całkowite wyeliminowanie tej sankcji karnej z krajowych porządków prawnych.

Oficjalne stanowiska Kościołów protestanckich, o ile w ogóle zostały sformułowane, to są zróżnicowane w zależności od konfesji.

Analizując zagadnienie w przypadku tych wyznań zreformowanych działających w Polsce, które nie opublikowały oświadczenia na temat kary głównej, odwoływano się do bogatego dorobku protestanckich Kościołów amerykańskich konkretnego nurtu. W wyniku przeprowadzonych analiz można sformułować wniosek, że na gruncie współczesnego protestantyzmu opinie poszczególnych wspólnot na temat kary głównej są w większości abolicjonistyczne, choć nie jest to zasadą.

\footnotetext{
${ }^{29}$ Z. Pasek, Ruch zielonoświatkowy, Kraków 1992, s. 108.

${ }^{30}$ Por. Assemblies of God, Capital punishment, http://www.ag.org/top/Beliefs/contempissues_08_capital_punish.cfm (26.06.2014).
} 


\section{Abstrakt}

\section{Glówne Kościoły protestanckie w Polsce wobec kary śmierci}

Artykuł ukazuje stanowisko głównych wyznań protestanckich funkcjonujących w Polsce na temat kary śmierci. W pierwszej części opisane jest zjawisko kary śmierci jako takiej. Autor nie zajmuje się wątkiem doktrynalnym kary śmierci jako takiej i tym, czy jest to w ogóle kara. Bardzo krótko opisuje historię kary kapitalnej i jej obecne funkcjonowanie na świecie. W dalszej części następuje zdefiniowanie protestantyzmu jako jednej z konfesji chrześcijańskich (obok katolicyzmu i prawosławia). Wskazane są elementy istotne i charakterystyczne dla protestanckich wspólnot wyznaniowych. Ostatnia i najobszerniejsza część wprost zajmuje się problemem wskazanym w tytule. Opisane zostaje stanowisko sześciu największych Kościołów protestanckich w Polsce odnośnie do kary śmierci. W większości przypadków problemem okazał się brak oficjalnych dokumentów czy wypowiedzi przedstawicieli na temat poruszanej problematyki. Zasadne było zatem odwołanie się do źródeł zagranicznych traktujących o karze śmierci (zwłaszcza z USA) pochodzących od Kościołów z danej gałęzi protestanckiej. Celem artykułu nie było poruszanie kwestii zasadności stosowania kary śmierci czy też rozpatrywanie jej pod względem nauki prawa karnego. Zebrane zostały jedynie stanowiska największych wspólnot reformowanych w Polsce, by ukazać ich stosunek do najwyższego wymiaru kary.

Słowa kluczowe: kara śmierci, protestantyzm, Kościoły reformowane, Polska

\section{Abstract}

\section{Reformed Churches in Poland regarding capital punishment}

The sole purpose of this article is to show the position of the major protestant denominations in Poland, towards the death penalty. The first part describes a death penalty phenomenon. The author does not deal neither with a doctrinal theme of the death penalty, nor with its relevance in context of punishment. Instead, he briefly describes the history of the capital punishment and its occurrence around the world. The next part defines protestantism as one of the christian confessions (beside Catholicism and Orthodoxy). Within this section there are presented essential aspects of Protestant faith communities. Last and the largest part deals directly with a problem indicated in the title. Chapter refers to the six largest protestant churches in Poland and their position towards the death penalty. In most cases, the problem was lacking official documents or statements of representatives regarding described issues. Therefore it was reasonable to refer to the foreign sources treating about death penalty (especially from the USA), originated from the churches of given protestant branch. The aim of this article is not to discuss the legitimacy of the death penalty, or to examine it in terms of criminal law, but to gather necessary information about major reformed communities in Poland, in order to show their attitudes toward capital punishment. 
Keywords: capital punishment, Protestantism, Poland, Reformed Churches

\section{Bibliografia}

Assemblies of God, Capital punishment, http://www.ag.org/top/Beliefs/ contempissues_08_capital_punish.cfm (26.06.2014).

Bartusiak B., Kara śmierci w świetle sporu o racjonalizacją kary, Warszawa 2011.

Bentkowski A., Czy nowy kodeks karny bez kary śmierci?, „Palestra” 1994 nr 7-8, s. 130-141.

Death sentences and executions 2013, Amnesty International Publications 2014, http://www. amnestyusa.org/research/reports/death-sentences-and-executions-2013 (28.06.2014).

Encyklopedia prawa, red. U. Kalina-Prasznic, Warszawa 2007.

Gajewski W., Kościół zielonoświatkowy: geneza, dzieje, teologia, duchowość i perspektywy, [w:] Nierzymskokatolickie Kościoły chrześcijańskie we współczesnej Polsce, red. Z. J. Winnnicki, T. Dębowski, Torun 2007.

Grześkowiak A., Kara śmierci w polskim prawie karnym, Torun 1982.

Hinz M., Marcin Luter - ojciec etyki ewangelickiej, [w:] M. Luter, Pisma etyczne, Bielsko-Biała 2009 (Biblioteka Klasyki Ewangelickiej, 6).

Kalwin J., O zwierzchności świeckiej, porządne wedtug sznuru Pisma świętego opisanie. Zaraz o pożytkach i powinnościach urzędu jej. Z łacińskiego na polskie wiernie przetlumaczone, oprac. W. Kriegseisen, Warszawa 2009.

Luter M., Pisma etyczne, Bielsko-Biała 2009 (Biblioteka Klasyki Ewangelickiej, 6).

Marek A., Prawo karne, Warszawa 2009.

Mitera M., Zubik M., Kara śmierci w świetle doświadczeń wspótczesnych systemów prawnych, Warszawa 1998.

Nowa encyklopedia powszechna PWN, red. B. Petrozolin-Skowrońska, t. 5, Warszawa 1995.

Oświadczenie Kościoła Ewangelicko-Augsburskiego w sprawie ochrony życia z 1991 r., http://old.luteranie.pl/p1/?D=3353 (29.06.2014).

Pasek Z., Ruch zielonoświątkowy, Kraków 1992.

Reformed Church in America, Position on capital punishment (2000), https://www.rca. org/ sslpage.aspx?pid=496 (29.06.2014).

Reid G. W., Death penality, http://dialogue.adventist.org/articles/08_1_kubo_e.htm (24.06.2014).

Southern Baptist Convention, Resolution on capital punishment (2000), http://www.sbc. net/ resolutions/299 (26.06.2014).

Stępień M., Kodeks Hammurabiego, Warszawa 1996.

United Church of Christ, Capital punishment, http://www.ucc.org/justice/criminal-justice/ death-penalty.html (30.06.2014).

Warylewski J., Kara-podstawy filozoficzne i historyczne, Gdańsk 2007.

Wesley J., Bible commentary notes, http://www.godrules.net/library/wesley/wesleyrom13.html (25.06.2014). 
Włodarski S., Tarowski W., Kościoły chrześcijańskie, Warszawa 1968.

Zasady socjalne 2000-2004. Nauka społeczna Zjednoczonego Kościoła Metodystycznego, Warszawa 2003.

Zieliński T. J., Krótka informacja o Kościele baptystycznym, http://www.baptysci.pl/kosciol/ 1141-krotka-informacja-o-kosciele-baptystycznym (25.06.2014). 